\title{
A Study on Assessment of Knowledge and To Create A wareness Regarding COVID-19 Infection and Its Preventive Measures among Health Care Students and Non-Health Care Students
}

\author{
Ch. O. V. Nagateja ${ }^{1}$, P. Bhavya Sree ${ }^{1}$, G. Padma Sri ${ }^{1}$, E. Jajili ${ }^{2}$ \\ ${ }^{1}$ Pharm. D, Sir C. R. Reddy College of Pharmaceutical Sciences, Eluru, Andhra Pradesh, INDIA. \\ ${ }^{2}$ Assistant Professor, Sir C. R. Reddy College of Pharmaceutical Sciences, Eluru, Andhra Pradesh, INDIA. \\ Corresponding Author: Ch. O. V. Nagateja
}

\begin{abstract}
Background: The World Health Organization (WHO) declared covid-19 as a pandemic on $11^{\text {th }}$ march 2020. Since no treatment is available, following preventive measures is only the effective way to stop the spread of covid-19. This study aimed to assess knowledge regarding covid-19 and its preventive measures and to create awareness about covid-19 among healthcare students and non-healthcare students. Methods: An online cross sectional study was conducted in 2 months i.e., from $1^{\text {st }}$ Aug. 2020 to $30^{\text {th }}$ Sept. 2020 among healthcare students and non-health care students. To determine the scoring of questionnaire, mean of knowledge scores and standard deviation were calculated.
\end{abstract}

Results: A total of 766 students were participated in this study. The age of participants ranged from 18 to 23. Males were 496 and females were 270 . Health care students were 423 and 343 students are non-health care students. Overall knowledge about covid-19 infection was good among 480 students, average among 183 students and was poor among 103 students. The mean knowledge score of healthcare students (8.41) is higher than nonhealth care students (6.11) towards covid-19 infection and its preventive measures.

Conclusion: This study reveals that majority of the students were knowledgeable about covid-19 infection and its preventive measures. The mean knowledge score of healthcare students (8.41) is higher than non-health care students (6.11) indicating that the health care students have more knowledge. Though the overall knowledge on covid-19 was good enough among health care students and non-health care students, still there is a need for education to increase knowledge especially among non-health care students.

Keywords: SARS-COV 2 virus, Covid-19 infection, health care students, non-healthcare students, knowledge, awareness, India.

\section{INTRODUCTION}

A novel coronavirus is a new strain of the infectious disease that was not previously identified in humans ${ }^{[1]}$ that causes a coronavirus disease 2019, is an emerging disease that was first identified in Wuhan (China) on December 2019, so named as COVID-19.

The World Health Organization (WHO) declared COVID-19 as an international public health emergency and requests all countries for collaborative efforts to break the chain of spreading. ${ }^{[2]}$

In December 2019, there was an increase in pneumonia cases of unknown reason over the world. World Health Organisation named this disease as COVID19 (Corona virus Disease 2019) on $11^{\text {th }}$ February 2020. This novel corona virus is to be believed to get spread from the bat and later on a human to human transmission. ${ }^{[3]}$ Coronavirus disease (COVID-19) is caused by SARS-COV 2 virus. 
Coronavirus is one of the majorperson cough or sneeze then the droplets are pathogens that mainly targets the humanleads to the transmission. ${ }^{[13]}$

respiratory system (lungs). Previous outbreaks of coronaviruses include Middle East respiratory syndrome (MERS)-Cov and the severe acute respiratory syndrome (SARS)-Cove which have been previously characterized as agents that are a great public health threat. ${ }^{[4]}$

Researchers across the globe are working continuously on transmission routes, treatments, and outcomes of COVID-19. ${ }^{[5,6]}$

Covid-19 is a single-stranded RNA virus. The nucleocapsid protein formed the capsid outside the genome and the genome is further packed by an envelope and is associated with structural proteins. It primarily infect human lung cells through a receptor for an enzyme called Angiotensin Converting Enzyme 2 (ACE2). ${ }^{[7,8]}$

Covid-19 patients may be asymptomatic or they may have flu-like symptoms. There is no specific treatment for Covid-19 infection, so health care providers treat the symptoms with supportive care. ${ }^{[9]}$

The incubation period is thought to be within 14 days following exposure, with most cases occurring between four to five days of infection. ${ }^{[10]}$ This period may be different according to the age and the immunity of the patient which can unmatch the frame of time.

The most common symptoms at onset of covid-19 illness are fever, cough, fatigue and others include sputum production, headache, haemoptysis, diarrhoea, dyspnoea. During March 2020, anosmia (loss of smell) was reported in some cases. ${ }^{[11]}$

Clinical features revealed by CT scan presented as Pneumonia, in some cases the multiple peripheral ground glass opacities were observed in sub pleural regions of both lungs. ${ }^{[12]}$

Individual- to -individual transmissions happens principally employing when the infected person came directly in touch with the non-infected person or when the infected

\section{COVID- 19 IN INDIA}

The Government of India has taken stringent preventive and precautionary measures against covid-19 to control its spread, safeguard citizens and ensure their well-being. Arogya Setu (literally, bridge for disease freeness) a mobile application to connect essential health services with the people of India was developed by government of India. ${ }^{[14]}$

The first case in India was reported in the state of Kerala in January 2020 in student returning from china due to the lock down in the Wuhan city due to the virus outbreak.

After 14 hours voluntarily public curfew named as Janata Curfew, India immediately announced the implementation of a national wide complete lockdown, which only allowed essential services to operate over so million people of India.

COVID-19 has reached the pandemic state and it's necessary to follow preventive measures to eradicate the spread of disease. ${ }^{[15]}$ It is also necessary for the public to know about covid-19 infection. For this reason we aimed to investigate the knowledge towards the present emerging health crisis among students (both health care and non-health care students).

The aim of the current cross sectional study is to assess the knowledge and to create awareness about covid-19 infection and its preventive measures among students (both health care and nonhealth care students)

\section{MATERIALS AND METHODS}

Study design: Prospective cross sectional study

Study duration: This study was conducted in 2 months i.e., from $1^{\text {st }}$ Aug. 2020 to $30^{\text {th }}$ Sept. 2020 among healthcare and nonhealth care students

Study population: 766 students were participated in this study. 
Source of data and materials: This study was conducted during the days of lockdown. Due to corona virus outbreak it was difficult to do community based study, so an online study was designed. So a Google form containing questions was created and shared it to social media like gmail, WhatsApp, Facebook, Instagram etc.

Study tool: Questionnaire composed of participant demographic details and questions regarding knowledge about covid-19. The questions were framed using information from WHO guidelines, ICMR guidelines, CDC guidelines and other government websites and standard publications.

The questions assessing knowledge regarding covid-19 infection were given with True, False and I don't know options. Each correct answer was scored with " 1 " point and an incorrect answer with" 0 " point. An overall score range of 0 to 10 is marked with greater than 8 points shows good knowledge.

Ethical consideration: The consent of participant was taken at the beginning of the survey. Participants who gave consent to participate in the survey would click the 'yes' button and they are directed to complete the questionnaire regarding covid19 knowledge

Table 1: Demographic details of the participants

\begin{tabular}{|l|l|l|l|l|}
\hline Synod & Demographic Variables & Sub Groups & No. of Students & Percentage \\
\hline $\mathbf{1 .}$ & Age & 18 & 6 & 0.7 \\
& & 19 & 132 & 17.2 \\
& & 20 & 90 & 11.7 \\
& & 21 & 263 & 34.3 \\
& & 22 & 211 & 27.5 \\
& & 23 & 64 & 8.3 \\
\hline $\mathbf{2 .}$ & Gender & Male & 496 & 64.8 \\
& & Female & 270 & 35.2 \\
\hline 3. & Education & Health Care Student & 423 & 55.2 \\
& & Non-Health Care Student & 343 & 44.8 \\
\hline 4. & Health Care Student & MBBS & 53 & 12.5 \\
& & Pharm.D & 105 & 24.8 \\
& & Bds/Mds & 61 & 14.4 \\
& & B.Sc Nursing & 61 & 14.4 \\
& & B.Pharm & 89 & 21 \\
& & Others(Physiotherapy etc) & 54 & 12.8 \\
\hline 5. & Non-Health Care Student & B.Tech/M.Tech & 113 & 32.9 \\
& & Degree & 112 & 32.6 \\
& & Agricultural & 71 & 20.6 \\
& & MBA & 47 & 13.89 \\
\hline
\end{tabular}

Among 423 health care students, 53 students are from MBBS, 105 students are

\section{STATISTICAL ANALYSIS}

Statistical analysis were performed on the data, simple percentages were calculated. The recorded data was compiled in spreadsheet (Microsoft Excel). To determine the scoring of questionnaire, mean of knowledge scores and standard deviation were calculated.

\section{RESULTS}

\section{DEMOGRAPHIC DETAILS:}

Age: A total of 766 students were participated in this study. The age of participants ranged from 18 to 23 (Mean20.5, Std.Dev- 1.87). Among 766 students, 17 students are of 18 years of age, 132 students are of 19 years, 90 students are of 20 years, 252 students are of 21 years, 211 students are of 22 years and 64 students are of 23 years of age. Most of the students participated in this study are of 19, 21 and 22 years of age.

Gender: Among 766 students, male students are 496 and female students are 270. Most of the students participated in this study are males.

Education: Among 766 students, 423 students are health care students and 343 students are non-health care students. Most of the students participated in this study are health care students.

from Pharm.D, 61 students are from BDS/MDS, 64 students are from B.Sc 
Nursing, 89 students are from B.Pharm, and remaining 54 students are from other health care courses such as physiotherapy, veterinary. Most of the health care students participated in this are from Pharm.D.

Among 343 non-Health care students, 113 students are from B.Tech/ M.Tech, 112 students are from Degree, 71 students are from agricultural courses and 47 students are from MBA course. Most of the non-health care students participated in this study is from B.Tech/ M. Tech.

\section{KNOWLEDGE REGARDING COVID- 19 AMONG HEALTH CARE AND NON HEALTH CARE STUDENTS}

The questionnaire assessing knowledge was answered on a True/ False basis and an additional I don't know option. 10 questions were asked about covid-19 infection and its preventive measures. An additional five general questions were asked to know their attitude and practice towards covid-19 infection, vaccination and lock down which were not given any score.

Table 2: Knowledge regarding Covid-19 among Healthcare students and Non-Health care students

\begin{tabular}{|c|c|c|c|c|c|c|c|c|}
\hline \multirow[b]{2}{*}{ Questions } & \multicolumn{2}{|l|}{ True } & \multicolumn{2}{|l|}{ False } & \multicolumn{2}{|l|}{$\begin{array}{l}\text { Don't } \\
\text { know }\end{array}$} & \multicolumn{2}{|l|}{$\begin{array}{l}\text { Correct } \\
\text { answer }\end{array}$} \\
\hline & $\begin{array}{l}\text { Health } \\
\text { care } \\
(\%)\end{array}$ & $\begin{array}{l}\text { Non- } \\
\text { health } \\
\text { care }(\%)\end{array}$ & $\begin{array}{l}\text { Health } \\
\text { care } \\
(\%)\end{array}$ & $\begin{array}{l}\text { Non- } \\
\text { health } \\
\text { care } \\
(\%) \\
\end{array}$ & $\begin{array}{l}\text { Health } \\
\text { care } \\
(\%)\end{array}$ & $\begin{array}{l}\text { Non- } \\
\text { health } \\
\text { care }(\%)\end{array}$ & $\begin{array}{l}\text { Health } \\
\text { care }(\%)\end{array}$ & $\begin{array}{l}\text { Non- } \\
\text { health } \\
\text { care } \\
(\%)\end{array}$ \\
\hline $\begin{array}{l}\text { 1. COVID-19 means corona virus } \\
\text { disease-2019 \& it is caused by } \\
\text { SARS-CoV2. }\end{array}$ & $\begin{array}{l}410 \\
(96.9)\end{array}$ & $\begin{array}{l}310 \\
(90.4)\end{array}$ & $\begin{array}{l}7 \\
(1.7)\end{array}$ & $\begin{array}{l}13 \\
(3.8)\end{array}$ & $\begin{array}{l}6 \\
(1.4)\end{array}$ & $\begin{array}{l}20 \\
(5.8)\end{array}$ & $\begin{array}{l}410 \\
(96.9)\end{array}$ & $\begin{array}{l}310 \\
(90.4)\end{array}$ \\
\hline $\begin{array}{l}\text { 2. The current estimated incubation } \\
\text { period of COVID } 19 \text { is } 2-14 \text { days } \\
\text { (COVID-19 symptoms appear } \\
\text { within } 2-24 \text { days). }\end{array}$ & $\begin{array}{l}376 \\
(88.9)\end{array}$ & $\begin{array}{l}245 \\
(71.4)\end{array}$ & $\begin{array}{l}20 \\
(4.7)\end{array}$ & $\begin{array}{l}35 \\
(10.2)\end{array}$ & $\begin{array}{l}27 \\
(6.4)\end{array}$ & $\begin{array}{l}63 \\
(18.4)\end{array}$ & $\begin{array}{l}376 \\
(88.9)\end{array}$ & $\begin{array}{l}245 \\
(71.4)\end{array}$ \\
\hline $\begin{array}{l}\text { 3. COVID-19 infection spread } \\
\text { through Respiratory droplets of } \\
\text { infected person, Close contact with } \\
\text { the infected person, Touching a } \\
\text { surface or object contaminated with } \\
\text { virus, Hand shaking. }\end{array}$ & $\begin{array}{l}380 \\
(89.8)\end{array}$ & $\begin{array}{l}253 \\
(73.8)\end{array}$ & $\begin{array}{l}18 \\
(4.3)\end{array}$ & $\begin{array}{l}47 \\
(13.7)\end{array}$ & $\begin{array}{l}25 \\
(5.9)\end{array}$ & $\begin{array}{l}43 \\
(12.5)\end{array}$ & $\begin{array}{l}380 \\
(98.8)\end{array}$ & $\begin{array}{l}253 \\
(73.8)\end{array}$ \\
\hline $\begin{array}{l}\text { 4. The main clinical symptoms of } \\
\text { COVID-19 are fatigue, fever, dry } \\
\text { cough, myalgia, shortness of breath } \\
\text { \& headache. }\end{array}$ & $\begin{array}{l}356 \\
(84.2)\end{array}$ & $\begin{array}{l}230 \\
(67.1)\end{array}$ & $\begin{array}{l}19 \\
(4.5)\end{array}$ & $\begin{array}{l}42 \\
(12.2)\end{array}$ & $\begin{array}{l}48 \\
(11.3)\end{array}$ & $\begin{array}{l}71 \\
(20.7)\end{array}$ & $\begin{array}{l}356 \\
(84.2)\end{array}$ & $\begin{array}{l}230 \\
(67.1)\end{array}$ \\
\hline $\begin{array}{l}\text { 5. Washing hands, wearing mask, } \\
\text { avoid going to crowded places, } \\
\text { disinfecting contaminated surfaces, } \\
\text { maintaining social distance ( } 3 \text { feet) } \\
\text { from others are the preventive } \\
\text { measures of COVID-19. }\end{array}$ & $\begin{array}{l}366 \\
(86.5)\end{array}$ & $\begin{array}{l}278 \\
(81)\end{array}$ & $\begin{array}{l}17 \\
(4)\end{array}$ & $\begin{array}{l}32 \\
(9.3)\end{array}$ & $\begin{array}{l}40 \\
(9.5)\end{array}$ & $\begin{array}{l}33 \\
(9.6)\end{array}$ & $\begin{array}{l}366 \\
(86.5)\end{array}$ & $\begin{array}{l}278 \\
(81)\end{array}$ \\
\hline $\begin{array}{l}\text { 6.Older adults and those with severe } \\
\text { chronic illness such as lung or heart } \\
\text { diseases, Hypertension, Diabetes etc. } \\
\text { are at high risk of getting infected } \\
\text { with covid-19. }\end{array}$ & $\begin{array}{l}354 \\
(83.7)\end{array}$ & $\begin{array}{l}229 \\
(66.8)\end{array}$ & $\begin{array}{l}28 \\
(6.6)\end{array}$ & $\begin{array}{l}52 \\
(15.2)\end{array}$ & $\begin{array}{l}41 \\
(9.7)\end{array}$ & $\begin{array}{l}62 \\
(18.1)\end{array}$ & $\begin{array}{l}354 \\
(83.7)\end{array}$ & $\begin{array}{l}229 \\
(66.8)\end{array}$ \\
\hline $\begin{array}{l}\text { 7. Isolation \& treatment of people } \\
\text { who are infected with the COVID- } \\
19 \text { virus are effective ways to reduce } \\
\text { the spread of COVID-19 virus }\end{array}$ & $\begin{array}{l}347 \\
(82)\end{array}$ & $\begin{array}{l}252 \\
(73.5)\end{array}$ & $\begin{array}{l}31 \\
(7.3)\end{array}$ & $\begin{array}{l}43 \\
(12.5)\end{array}$ & $\begin{array}{l}45 \\
(10.6)\end{array}$ & $\begin{array}{l}48 \\
(14)\end{array}$ & $\begin{array}{l}347 \\
(82)\end{array}$ & $\begin{array}{l}252 \\
(73.5)\end{array}$ \\
\hline $\begin{array}{l}\text { 8. Currently there is no specific } \\
\text { treatment for COVID-19, but early } \\
\text { symptomatic \& \& supportive } \\
\text { treatment can help most patients } \\
\text { recover from the infection. }\end{array}$ & $\begin{array}{l}355 \\
(83.9)\end{array}$ & $\begin{array}{l}240 \\
(70)\end{array}$ & $\begin{array}{l}42 \\
(9.9)\end{array}$ & $\begin{array}{l}55 \\
(16)\end{array}$ & $\begin{array}{l}26 \\
(6.1)\end{array}$ & $\begin{array}{l}48 \\
(14)\end{array}$ & $\begin{array}{l}355 \\
(83.9)\end{array}$ & $\begin{array}{l}240 \\
(70)\end{array}$ \\
\hline $\begin{array}{l}\text { 9. People who have contact with the } \\
\text { person infected with COVID-19 } \\
\text { virus should be immediately isolated } \\
\text { in proper place }\end{array}$ & $\begin{array}{l}353 \\
(83.5)\end{array}$ & $\begin{array}{l}256 \\
(74.6)\end{array}$ & $\begin{array}{l}39 \\
(9.2)\end{array}$ & $\begin{array}{l}43 \\
(12.5)\end{array}$ & $\begin{array}{l}31 \\
(7.3)\end{array}$ & $\begin{array}{l}44 \\
(12.8)\end{array}$ & $\begin{array}{l}353 \\
(83.5)\end{array}$ & $\begin{array}{l}256 \\
(74.6)\end{array}$ \\
\hline $\begin{array}{l}\text { 10. It is not necessary for children } \\
\text { and young adults to take measures } \\
\text { to prevent the COVID-19 infection }\end{array}$ & $\begin{array}{l}138 \\
(32.6)\end{array}$ & $\begin{array}{l}116 \\
(33.8)\end{array}$ & $\begin{array}{l}263 \\
(62.2)\end{array}$ & $\begin{array}{l}184 \\
(53.6)\end{array}$ & $\begin{array}{l}22 \\
(5.2)\end{array}$ & $\begin{array}{l}43 \\
(12.5)\end{array}$ & $\begin{array}{l}263 \\
(62.2)\end{array}$ & $\begin{array}{l}184 \\
(53.6)\end{array}$ \\
\hline
\end{tabular}

On asking about Covid-19 caused by SARS-CoV2, 410 health care students and 310 non- health care students said correct answer which indicates most of the students were aware of covid-19 cause. 
Ch. O. V. Nagateja et.al. A study on assessment of knowledge and to create awareness regarding COVID-19 infection and its preventive measures among health care students and non-health care students.

For the question related to incubation period of covid-19, 376 health care students and 245 non-health care students said correct answer and for spreading of covid-19 infection question, 380 health care students and 253 non-health care students said correct answer.

On questioning about Covid-19 symptoms, correct answer was said by 356 health care students and 230 non-health care students.

On questioning about Covid-19 preventive measures, the correct answer is true which is said by 366 health care students and 278 non-health care students.

On asking about risk of covid-19 infection in older adults and other diseased patients, 354 health care students and 229 non-health care students answered correctly.

On questioning about effective ways to reduce covid-19 spread, the correct answer was said by 347 health care students and 252 non-health care students.

On asking about covid-19 treatment, 55 health care students and 240 non-health care students said correct answer.
When questioning about isolation of patients infected with covid-19, 353 health care students and 256 non health care students gives correct response.

For the question, it is not necessary for children and young adults to take measures to prevent the covid-19 infection; the correct answer is False and is said by 263 health care students and 184 non health care students. Most of the students were failed to answer this question correctly.

\section{ATTITUDE AND PRACTICE TOWARDS COVID-19, VACCINATION AND LOCK DOWN}

When questioning the participants about their attitude and practices towards covid-19 infections, most of the students said that they were following covid-19 rules and they will inform to healthcare officer if they got symptoms related to covid-19.

Most of the students got information related to covid-19 from news channels and TV followed by government hospitals and websites, social media, family and friends.

\begin{tabular}{|c|c|c|}
\hline Questions & $\begin{array}{l}\text { Healthcare } \\
\text { students }(\%)\end{array}$ & $\begin{array}{l}\text { Non-health } \\
\text { Care } \\
\text { students } \\
(\%)\end{array}$ \\
\hline $\begin{array}{l}\text { 1. Are you following COVID-19 preventive measures like washing hands, wearing mask, social } \\
\text { distance. } \\
\text { Yes } \\
\text { No } \\
\text { Sometimes }\end{array}$ & $\begin{array}{l}332(78.5) \\
39(9.2) \\
52(12.3)\end{array}$ & $\begin{array}{l}242(70.6) \\
53(15.5) \\
48(14)\end{array}$ \\
\hline $\begin{array}{l}\text { 2. If you are suffering from any of the symptoms of COVID-19, will you go to hospital/ inform to the } \\
\text { health care officer } \\
\text { Yes } \\
\text { No } \\
\text { May be }\end{array}$ & $\begin{array}{l}315(74.5) \\
42(9.9) \\
66(15.6)\end{array}$ & $\begin{array}{l}230(67.1) \\
41(12) \\
72(21)\end{array}$ \\
\hline $\begin{array}{l}\text { 3. Where did you get the information related to COVID-19 } \\
\text { News Channels, TV } \\
\text { Govt hospitals \& websites } \\
\text { Social media } \\
\text { Family \& friends }\end{array}$ & $\begin{array}{l}182(43) \\
107(25.3) \\
54(12.8) \\
80(18.9)\end{array}$ & $\begin{array}{l}142(41.4) \\
96(28) \\
58(16.9) \\
47(13.7)\end{array}$ \\
\hline $\begin{array}{l}\text { 4. What is the name of the company located in Hyderabad that has been trying to develop vaccine } \\
\text { against COVID-19 } \\
\text { Bharath Biotech } \\
\text { Novartis } \\
\text { Dr.Reddy's Laboratories } \\
\text { Hetero }\end{array}$ & $\begin{array}{l}310(73.3) \\
47(11.1) \\
43(10.2) \\
23(5.4) \\
\end{array}$ & $\begin{array}{l}225(65.6) \\
66(19.2) \\
31(9) \\
21(6.1) \\
\end{array}$ \\
\hline $\begin{array}{l}\text { 5. Do you agree that lock down in India will be useful for controlling COVID-19 infection } \\
\text { Yes } \\
\text { No } \\
\text { Don't know }\end{array}$ & $\begin{array}{l}309(73) \\
57(13.5) \\
57(13.5)\end{array}$ & $\begin{array}{l}223(65) \\
46(13.4) \\
74(21.6)\end{array}$ \\
\hline
\end{tabular}

When questioning the participants about the vaccination i.e., name of the company located in Hyderabad that has been trying to develop vaccine against 
COVID-19, most of the students said Bharath Biotech, followed by Novartis, Dr. Reddy's Laboratories and Hetero. The correct answer is Bharath biotech and it is said by 310 health care students and 225 non health care students.

When questioning the participants that lock down in India will be useful for controlling covid-19 infection, 309 healthcare and 223 non-health care students said yes. 57 health care and 46 nonhealthcare students said no. Remaining 57 health care students and 74 non health care students said they don't know.

\section{LEVEL OF KNOWLEDGE}

Level of Knowledge was assessed about covid-19 infection and its preventive measures. Knowledge is categorised into good, average and poor.

The participants who scored 8 to 10 points, considered them as having good knowledge, who scored 6 to 7 points as having average knowledge and those scored less than 5 as having poor knowledge.

Overall knowledge about covid-19 infection and its preventive measures was good among 480 students, average among 183 students and was poor among 103 students.

Among the 480 students who were having good knowledge, 318 students were health care students and 162 students were non-health care students.

Among the 183 students who were having average knowledge, 78 students were health care students and 105 students were non-health care students.

Among the 103 students who were having poor knowledge, 27 students were health care students and 76 students were non-health care students.

Table -4: Level of knowledge among healthcare students and non-health care students

\begin{tabular}{|l|l|l|l|}
\hline Level of knowledge & Health care $(\boldsymbol{\%})$ & Non health care $(\boldsymbol{\%})$ & Total students $(\boldsymbol{\%})$ \\
\hline Good knowledge ( 8-10points ) & $318(75.1)$ & $162(47.3)$ & $480(62.6)$ \\
\hline Average knowledge (6-7points) & $78(18.4)$ & $105(30.6)$ & $183(23.9)$ \\
\hline Poor knowledge (below 5 points) & $27(6.38)$ & $76(22.1)$ & $103(13.5)$ \\
\hline Total & $423(100)$ & $343(100)$ & $766(100)$ \\
\hline
\end{tabular}

\section{MEAN OF KNOWLEDGE SCORES}

The mean knowledge score of students aged 23 was high followed by students of aged 21, 22, 19, 20, and 18 . When compared to males, females have somewhat high mean knowledge score.

There is no significant difference between means of males (7.26) and females
(7.61), but females have somewhat higher mean of knowledge score than males.

The mean knowledge score of healthcare students (8.41) is higher than non-health care students (6.11) indicating that the health care students have more knowledge towards covid-19 infection and its preventive measures than non-health care students.

Table- 5: Mean and standard deviation of knowledge scores of students according to their age, gender and education

\begin{tabular}{|l|l|l|l|}
\hline S.No & Demographic variables & Sub groups & Mean(standard deviation) of knowledge scores \\
\hline 1. & Age & 18 & $6.5(1.37)$ \\
& & 19 & $7.25(2.12)$ \\
& & 20 & $7.24(2.14)$ \\
& & 21 & $7.44(2.08)$ \\
& & 22 & $7.33(2.13)$ \\
\hline 2. & Gender & 23 & $7.8(1.97)$ \\
\hline 3. & Education & Male & $7.26(2.10)$ \\
& & Female & $7.61(2.08)$ \\
\hline
\end{tabular}

\section{DISCUSSION}

Covid-19 is rapidly spreading in India. Currently there is proven treatment, prevention is the most important measure that can be taken. For that people need to be 
educated about the covid-19 infection and its preventive measures.

The identification and isolation of a suspected case is the most important step in curbing the spread of covid-19.

India is having lockdown measures since $25^{\text {th }}$ march 2020. During this period all students were at their home. Whatever level of knowledge and awareness they were having during this survey, possibly it might have been gained through previous orientation and training during the course study and presently by social media, internet, news channels, official web sites etc.

We present here a study of assessment of knowledge of covid-19 among healthcare and non-health care students. This study provides an insight into the knowledge and awareness of healthcare and non-health care students on covid-19 at the time of outbreak in 2020.

Among the students who participated in this study, most of the students are healthcare students followed by non-health care students. Their age ranged from 18 to 23. Most of the responses are received from males followed by females. The overall responses to the study were satisfactory because, overall a correct response of knowledge about covid-19 and its preventive measures was recorded at $78 \%$.

While assessing the knowledge about covid-19, it was found that health care students have more knowledge than nonhealth care students. The mean knowledge score of health care students is higher than mean knowledge score of non-health care students.

Most of the students (62.6\%) scored 8 to 10 points indicating that all these students are aware of covid-19 infection and its preventive measures. $23.9 \%$ students were having average knowledge and $13.5 \%$ were having poor knowledge, indicating that these students are unaware of covid-19 infection and preventive measures and they have to be counselled about covid-19 and its preventive measures.
Health education programs aimed at improving covid-19 knowledge are necessary to present positive attitudes and maintain appropriate practices. This study reveals the level of knowledge regarding covid-19 outbreak among students.

When questioning about cause of covid-19, incubation period, symptoms, spread, and risk of infection in adults, treatment and preventive measures, majority of the students (health care and non-health care) are answered correctly.

Most of the health care and nonhealth care students are answered incorrectly when they asked about preventive measures in children.

While assessing the attitude and practice towards covid-19, most of the students were following covid-19 rules and they were all said yes if they got symptoms related to covid-19, they will definitely inform to health care professional.

Most of the students got information related to covid-19 is from news channels and TV followed by government hospitals and websites, social media, family and friends.

While assessing the knowledge related to covid-19 vaccine, most of the students said correct answer indicating that they are aware of vaccine and were following updates on covid-19 vaccine.

Most of the students answered yes to the question that lockdown in India will be useful for controlling covid-19 infection, which indicates they have positive attitude towards lockdown and they are following covid-19 preventive rules.

By doing this study we tried to improve the knowledge about covid-19 infection and its preventive measures among those who had poor knowledge.

\section{CONCLUSION}

The Covid-19 pandemic has affected the world in various ways. The deficiency of information, the need for accurate information, and the rapidity of its dissemination are important, as this 
Ch. O. V. Nagateja et.al. A study on assessment of knowledge and to create awareness regarding COVID-19 infection and its preventive measures among health care students and non-health care students.

pandemic requires the cooperation of entire populations.

Despite many awareness programs conducted by government and other agencies, there are certain false beliefs among the students (both health care and non-health care) towards the transmission, prevention and treatment of covid-19.

The mean knowledge score of health care students is higher than mean knowledge score of non-health care students indicating health care students have more knowledge than non-health care students.

A considerable fraction of students (both health care and non-health care students) were having poor knowledge towards the transmission of new corona virus, prevention and treatment.

Though the overall knowledge on covid-19 was good enough among health care students and non-health care students, still there is a need for education to increase knowledge especially among non-health care students

Most of the students following precautions to prevent spread of covid-19 infection. Most of the students are positive towards the lockdown and they were believing that lockdown in India will be helpful for controlling spread of covid-19 infection.

To conclude, the present study revealed that health care students have more knowledge towards covid-19 infection and its preventive measures than non-health care students.

The results of this study suggest that higher attention should be given to nonhealthcare students.

\section{ACKNOWLEDGEMENT}

The authors would like to thank all the participants for participating in this study, without whom the study would not be feasible.

\section{Conflict of Interest: None}

Source of Funding: None

\section{Ethical Approval: Approved}

\section{REFERENCES}

1. Sahbanathul Missriya Ma1, Suhail Hassan. Assess The Awareness And Attitude Regarding Prevention Of Coronavirus Disease 2019. Asian Journal Of Pharmaceutical And Clinical Research. 2020; 13(7): 95-98.

2. Muhammad Wajahat , Hasnat Ahmed, Sikander Khan Sherwani. Knowledge, Attitude And Practice Towards Covid-19 Among General Public Of Islamabad, Pakistan. International Journal Of Basic Medical Sciences And Pharmacy. 2020; 9(1).

3. Devendra Kumar Mishra, Vivek Srivastava, Dipti Srivastava, Himani Awasthi,A Review on the COVID-19 (Novel Coronavirus) Characteristics, Evaluation, and Treatment. Int. J. Pharm. Sci. Rev. Res. 2020; 63(1): 200-205.

4. Rothan HA, Byrareddy SN. The epidemiology and pathogenesis of coronavirus disease (COVID-19) outbreak.J Autoimmun. 2020;109: 102433.

5. Sarfi S, Farooq S. Knowledge, Awareness, Attitude and Skills of Dental Surgeons of Kashmir on COVID-19. Ann. Int. Med. Den. Res. 2020; 6(4): DE26-DE30.

6. Zhong BL, Luo W, Li HM, et al. Knowledge, attitudes, and practices towards COVID-19 among Chinese residents during the rapid rise period of the COVID-19 outbreak: a quick online cross-sectional survey. Int J Biol Sci. 2020;16(10): 17451752.

7. Mittal A, Manjunath K, Ranjan RK, Kaushik S, Kumar S, Verma V. COVID-19 pandemic: Insights into structure, function, and hACE2 receptor recognition by SARSCoV-2. PLoS Pathog. 2020;16(8): e1008762.

8. Leila Mousavizade, Sorayya Ghasemi, Genotype and phenotype of COVID-19: Their roles in pathogenesis. Journal of Microbiology, Immunology and Infection. 2020.

9. Corona virus - similarities and differences. https://www.who.int/news-room/q-adetail/coronavirus-disease-covid-19similarities-and-differences-with-influenza.

10. Sai Ravi Teja Kamineni, Pandian Balu, Poonguzhali Sivagananam, et al. 
Ch. O. V. Nagateja et.al. A study on assessment of knowledge and to create awareness regarding COVID-19 infection and its preventive measures among health care students and non-health care students.

Knowledge of COVID-19 among nursing and Allied health care professionals working in tertiary care hospital. International Journal of Research in Pharmaceutical Sciences. 2020; 11(SPL1): 103-109.

11. Wu, Yi-Chi, Ching-Sung, Yu-Jiun .The outbreak of COVID-19: An overview. Journal of the Chinese Medical Association. 2020 ; 83(3): 217-220 .

12. Akalu Y, Ayelign B, Molla MD. Knowledge, Attitude and Practice Towards COVID-19 Among Chronic Disease Patients at Addis Zemen Hospital, Northwest Ethiopia. Infect Drug Resist. 2020; 13: 1949-1960.

13. Jyoti\& Khina Sharma. Cross Sectional Study On Knowledge And Practices Among Indian Nurses About Covid-19. The
Malaysian Journal of Nursing (MJN). 2020; 12(2): 22-27.

14. Kaushik M, Agarwal D, Gupta Ak. CrossSectional Study On The Role Of Public Awareness In Preventing The Spread Of Covid-19 Outbreak In India. Postgraduate Medical Journal. 2020.

15. Ministry Of Health And Family Welfare (Government Of India): COVID-19 India https://mohfw.gov.in/

How to cite this article: Ch. O. V. Nagateja, P. Bhavya Sree, G. Padma Sri et.al. A study on assessment of knowledge and to create awareness regarding COVID-19 infection and its preventive measures among health care students and non-health care students. International Journal of Science \& Healthcare Research. 2021; 6(2): 108-116. DOI: https://doi.org/10.52403/ijshr.20210420 